\title{
PERBANDINGAN PATOGENESITAS, Edwardsiella tarda PADA IKAN MAS KOKI (Charassius auratus) DAN IKAN CELEBES RAINBOW (Telmatherina celebensis)
}

\author{
Siti Narwiyani*) dan Kurniasih ${ }^{* * *}$ \\ ") Balai Besar Karantina Ikan Hasanuddin, Makassar \\ Jl. Dakota No. 24, Makassar 90242 \\ E-mail: stnarwiyani@gmail.com \\ **) Fakultas Kedokteran Hewan, Universitas Gajah Mada, Yogyakarta \\ Jl. Farmako Sekip, Jogjakarta 55281
}

(Naskah diterima: 21 Juni 2011; Disetujui publikasi: 13 September 2011)

\begin{abstract}
ABSTRAK
Edwardsiella tarda adalah salah satu jenis bakteri yang masuk dalam daftar Hama Penyakit Ikan Karantina (HPIK) yang harus dicegah penyebarannya. Infeksi E. tarda terdapat pada berbagai jenis ikan budidaya maupun pada ikan yang hidup di perairan bebas. E. tarda juga menginfeksi vertebrata tingkat tinggi (burung dan reptil), mamalia, dan termasuk juga manusia. Pada manusia, dikenal sebagai penyebab penyakit gastrointestinal dan ekstraintestinal. Edwardsiella tarda sudah tersebar di beberapa negara di antaranya adalah Jepang, Taiwan, Thailand, Amerika Serikat, Singapura, dan Malaysia. Di Indonesia, E tarda ditemukan di Jawa, Sumatera, dan Kalimantan. E. tarda dapat diidentifikasi melalui gejala klinis, identifikasi secara morfologi, fisik, dan biokimia, serta molekuler DNA. Bakteri ini menyerang mekanisme pertahanan tubuh inang, karena itu, proses proliferasi bakteri ini sangat cepat di dalam inang dan menyebabkan kematian. Tingkat patogenitas E. tarda dapat ditentukan berdasarkan kemampuan bakteri tersebut untuk menginfeksi kekebalan non spesifik pada ikan. Perbedaan patogenitas E. tarda pada berbagai ikan air tawar di Indonesia belum pernah dilakukan. Tujuan penelitian ini adalah untuk membandingkan patogenitas dan $\mathrm{LC}_{50} E$. tarda pada ikan mas koki (Carassius auratus) dan ikan Celebes rainbow (Telmatherina celebensis). Untuk uji $\mathrm{LC}_{50}$ ikan uji disuntik dengan penyuntikan intraperitonial dengan konsentrasi bakteri $0,10^{2}, 10^{4}, 10^{6}, 10^{8}$, dan $10^{10} \mathrm{cfu} / \mathrm{mL}$, ikan dipelihara dalam akuarium selama 48 jam dan dihitung jumlah kematiannya setiap 12 jam. Nilai LC $_{50}$ untuk ikan mas koki dan ikan Celebes Rainbow adalah $1,8 \times 10^{5} \mathrm{cfu} / \mathrm{mL}$ dan $2,3 \times 10^{7} \mathrm{cfu} / \mathrm{mL}$. Uji patogenitas dilakukan dengan melakukan perendaman ikan uji dalam akuarium berukuran $30 \mathrm{~cm} \times 30 \mathrm{~cm} \times 50 \mathrm{~cm}$ dengan kepadatan 10 ekor/akuarium dan volume 20 air liter selama seminggu; dan kepadatan bakteri menggunakan nilai $\mathrm{LC}_{50}$ masingmasing ikan. Perubahan makroskopik patologik anatomik menunjukkan adanya lesi kemerahan pada ekor dan sirip, pembengkakan perut dan tubuh, insang pucat, lesi pada pangkal sirip dan ekor, dan pembengkakan pada hati dan ginjal pada ikan mas koki dan ikan Celebes rainbow.
\end{abstract}

KATA KUNCl: Edwardsiella tarda, patogenesitas, $\mathrm{LC}_{50}$, Carassius auratus, Telmatherina celebensis 
ABSTRACT: Pathogenicity comparison of Edwardsiella tarda infection in goldfish (Charassius auratus) and celebes rainbow (Telmatherina celebensis). By: Siti Narwiyani and Kurniasih

\begin{abstract}
Edwardsiella tarda is one species of bacteria that is listed in the list of Fish Disease Quarantine (HPIK) that should be prevented from spreading. Infections of E. tarda were found in farmed fish and wild fish. E. tarda also infected higher vertebrates (such as birds and reptiles), mammals, and including humans. The infection in humans, known to cause gastrointestinal and extraintestinal diseases. The most susceptible species of fish to the infection by E. tarda were catfish and eels. Edwardsiella tarda was spread across several countries including Japan, Taiwan, Thailand, the United States, Singapore, and Malaysia. In Indonesia, E. tarda was found in Java, Sumatra, and Kalimantan. E. tarda could be identified through its clinical symptoms; identification by morphological, physical, and biochemical as well as DNA molecular. These bacteria attack the body's host defense mechanisms; therefore the proliferation process of bacteria within the host is extremely rapid, and caused the death. The level of pathogenicity of E. tarda can be determined based on the ability of the bacteria to infect non-specific immunity in fish. Differences pathogenicity of $\boldsymbol{E}$. tarda in a variety of freshwater fish species in Indonesia has not been done. The purpose of this study was to compare the pathogenicity and $L C_{50}$ of E. tarda in Koki carp (Carassius auratus) and Celebes rainbow fish (Telmatherina celebensis). $L C_{50}$ values were obtained by injecting the fish intra peritoneal with bacteria and the concentration of bacteria were 0 (control), $10^{2}, 10^{4}, 10^{6}, 10^{8}$, and $10^{10} \mathrm{cfu} / \mathrm{mL}$. Fish were kept in the aquarium for 48 hours and the number of died fish were counted every 12 hours. $L C_{50}$ values for Koki carp and Celebes rainbow were $1.8 \times 10^{5} \mathrm{cfu} / \mathrm{mL}$ and $2.3 \times 10^{7} \mathrm{cfu} / \mathrm{mL}$, respectively. Pathogenecity test were performed by rearing the fish for a week in the $30 \mathrm{~cm} \times 30 \mathrm{~cm} \times 50 \mathrm{~cm}$ aquarium filled with 20 liters of water. The fish density was 10 ind./aquaria and the density of bacteria used $L C_{50}$ values for each fish. Macroscopic patological anatomy changes appeared on both fish species which are swelling of the stomach and body, pale gills, lesions at the base of the fins, and swelling of the liver and kidney.
\end{abstract}

KEYWORDS: Edwardsiella tarda, pathogenecity, $L C_{50}$, Carassius auratus, Telmatherina celebensis

\section{PENDAHULUAN}

E. tarda adalah salah satu jenis bakteri yang masuk dalam daftar Hama Penyakit Ikan Karantina (HPIK) yang harus dicegah penyebarannya. E. tarda telah ditemukan pada ikan nila dari Jogja, ikan mas dari Pontianak, ikan lele dari Sumatera, dan Lumajang, serta kura-kura Brasil yang diimpor ke Indonesia. Sesuai dengan Surat Keputusan Menteri Kelautan dan Perikanan Nomor: KEP.03/MEN/ 2010 tentang Jenis Hama dan Penyakit Ikan Karantina, Media Pembawa dan Sebarannya disebutkan bahwa Edwardsiella tarda merupakan jenis bakteri yang termasuk salah satu Hama Penyakit Ikan Karantina (HPIK) golongan II yang diartikan sebagai jenis penyakit yang sudah ada di wilayah Indonesia akan tetapi belum ada teknologi untuk penanggulangannya. Sehingga, apabila media pembawa dapat dibebaskan dari HPIK, komoditi tersebut dapat dilalulintaskan atau dapat dimasukkan ke wilayah Indonesia; tetapi apabila tidak dapat dibebaskan dari penyakit tersebut maka dilakukan penolakan/re-impor ke negara asal atau pemusnahan (Anonim, 1993).

Edwardsiellosis atau Emphisemathous Putrevactive Disease of Catfish (EPDC) yang disebabkan oleh E. tarda merupakan penyakit yang sudah dikenal sebagai penyakit utama pada budidaya catfish di Amerika. Perkembangan $E$. tarda umumnya sangat lambat. Salah satu faktor penyebab terjadinya infeksi E. tarda adalah karena ikan stres, terutama akibat tingginya padat tebar menjelang panen, kondisi kualitas air yang jelek, dan tingginya kandungan bahan organik. E. tarda merupakan agen penyebab Edwardsiellosis, yang dapat menyebabkan kematian pada ikan habitat air tawar maupun air laut (Thune et al., 1993). 
Infeksi E. tarda pada berbagai jenis ikan budidaya maupun pada ikan yang hidup di perairan bebas telah dilaporkan seperti: chanel catfish, eels, mullet, chinook salmon, flounder, carp, tilapia, dan stripedbass (Thune et al., 1993). Edwardsiella tarda menginfeksi vertebrata tingkat tinggi (burung dan reptil), mamalia (Rao et al., 2001), termasuk juga manusia (Plumb, 1999); pada manusia dikenal sebagai penyebab penyakit gastrointestinal dan ekstraintestinal (Janda \& Abbot, 1993). Spesies yang paling banyak terinfeksi oleh $E$. tarda adalah catfish dan eels (Meyer \& Bullock, 1973).

Infeksi Edwardsiellosis dapat menyebabkan mortalitas sampai $80 \%$ pada ikan sidat (Anguilla anguilla) di alam. Infeksi secara intraperitonial dari E. tarda sebanyak 8,0 $\times 10^{7}$ $\mathrm{cfu} / \mathrm{mL}$ terhadap 5 ekor ikan catfish ukuran 5 $10 \mathrm{~cm}$, pada suhu $27^{\circ} \mathrm{C}$, dapat membunuh 4 ekor ikan dalam waktu 10 hari. Ikan yang mati menunjukkan hemoragi (perdarahan) di sekitar kepala, operkulum, dan organ dalam (Meyer \& Bullock., 1973).

Edwardsiella tarda sudah tersebar di beberapa negara di antaranya adalah Eropa, Jepang, Taiwan, Thailand, Amerika serikat, Singapura, dan Malaysia. Di Indonesia, E. tarda sudah pernah ditemukan di Jawa, Sumatera, dan Kalimantan. E. tarda dapat diidentifikasi melalui gejala klinis, isolasi dan identifikasi secara morfologi dan molekuler DNA. Edwardsiella tarda merupakan penyebab septicemia dengan luka serius pada kulit, menyerang organ dalam seperti: hati, ginjal, limpa, dan otot. Bakteri ini menyerang mekanisme pertahanan tubuh inang, karena itu proses proliferasi bakteri ini sangat cepat di dalam inang dan menyebabkan kematian (Rao et al., 2001).

Perbedaan patogenitas E. tarda pada berbagai jenis ikan terutama ikan air tawar di Indonesia belum pernah dilaporkan secara rinci. Di Indonesia E. tarda telah ditemukan pada ikan nila dari Jogja, ikan mas dari Pontianak dan Pangkal Pinang Sumatera, ikan lele dari Semarang dan Lumajang, serta kurakura Brasil yang diimpor ke Indonesia. Edwardsiellosis dapat ditularkan secara horizontal antara ikan sakit dan ikan sehat (Post, 1987). Patogenesis E. tarda yang menginfeksi berbagai ikan telah dilaporkan seperti pada ikan Chinook Salmon (Amandi et al., 1982), ikan belut rawa liar di Asia (Lee et al., 2006), pada ikan Anabas Terstudineus atau ikan koi (Sahoo et al., 2000), dan pada mamalia laut seperti singa laut (Eumetopias jubata) (Coles et al., 1978).

Pengujian E. tarda dilakukan berdasarkan tingkat patogenitasnya, hal ini disebabkan patogenitas E. tarda yang terdapat pada satu spesies ikan dengan spesies yang lain berbeda, begitu pula untuk daerah sebaran yang satu dengan daerah sebaran lainnya berbeda (Frerichs \& Millar, 1993). Patogenitas bakteri dapat ditunjukkan dari aktivitas hemolitik pada darah dan organ internal ikan (Zhang \& Austin, 2000). Patogenitas E. tarda dipengaruhi oleh banyak faktor, dan kemungkinan pula penyebaran penyakit ini sudah terjadi, seperti antiphagocyte killing (Ainsworth \& Chen, 1983), hemolysin (Hirono et al., 1997), serum resistance, dan kemampuan sel epthelial (Janda et al., 1991; Ling et al., 2000). Walaupun masing-masing virulent dan virulent strain mampu menyerang sel-sel yang dikultur invitro, hanya virulent strain yang dapat masuk ke ikan dalam jumlah besar lewat mukus, insang dan gastrointestinal (Ling et al., 2000) dan organ-organ internal lainnya dan dapat menyebabkan kematian. Janda et al. (1991) menemukan bahwa patogenitas pada $E$. tarda tidak berhubungan dengan kandungan plasma, chemotactic motility, serum resistance, dan pengaruh pada aktivitas enzim yang dipilih. Sangat sedikit yang telah diketahui tentang faktorfaktor penyebab terjadinya penyakit tersebut.

Serum dan phagocyte-mediated killing merupakan 2 sistem pertahanan utama pada kekebalan non spesifik di ikan (Blazer, 1991; Dalmo et al., 1997 dalam Rao et al., 2001). Sistem pertahanan utama ini berfungsi menahan patogen yang dapat menginfeksi ikan. Tingkat patogenitas E. tarda dapat ditentukan berdasarkan kemampuan bakteri tersebut untuk menginfeksi kekebalan non spesifik pada ikan. Selain itu, patogenitas bakteri juga sangat banyak bergantung pada kecocokan inang (susceptable host). Pada inang yang tidak cocok, walaupun bakteri tersebut fatogenik untuk jenis ikan tertentu, maka tidak akan menimbulkan efek yang sama dengan inang yang cocok. Tujuan penelitian ini adalah untuk membandingkan patogenitas dan $\mathrm{LC}_{50}$ E. tarda pada ikan mas koki (Carassius auratus) dan ikan Celebes rainbow (Telmatherina celebensis). 


\section{METODE PENELITIAN}

\section{Populasi dan Sampel}

Isolat $E$. tarda diambil dari sampel ikan nila (Oreochromis niloticus) dari Jogjakarta, dan kura-kura impor dari Brazil (Trachemys script). Media isolasi yang digunakan adalah media darah yang diambil secara langsung dari darah kambing Blood Agar Plate, dan Trypticase Soy Agar (TSA).

Penelitian dilakukan mulai Maret 2010 sampai dengan Desember 2010 . Penelitian ini dilaksanakan di Laboratorium Patologi Fakultas Kedokteran Hewan Universitas Gajah Mada Jogjakarta dan Laboratorium Balai Besar Karantina Ikan Hasanuddin Makassar.

\section{Uji Lethal Concentration 50 ( $\left.\mathrm{LC}_{50}\right)$}

$\mathrm{Uji}_{\mathrm{LC}}$ dilakukan untuk mengetahui level konsentrasi infeksi E. tarda pada ikan uji. Pengembalian virulensi $E$. tarda dilakukan dengan menyuntikkan bakteri ke ikan nila dan kura-kura Brazil sehat. Setelah muncul tandatanda infeksi, kemudian isolat murni E. tarda ditumbuhkan pada media BHIB $10 \mathrm{~mL}$, diinkubasi selama 24 jam-48 jam pada suhu $25^{\circ} \mathrm{C}-30^{\circ} \mathrm{C}$. Bakteri kemudian dipanen $1 \mathrm{~mL}$ lalu ditambahkan larutan buffer saline solution sebanyak $9 \mathrm{~mL}$. Suspensi diencerkan secara bertingkat $\left(10^{-1}\right.$, sampai dengan konsentrasi 10-12). Hasil pengenceran E. tarda tersebut diinfeksikan ke ikan uji, masing-masing 10 ekor sebanyak $0,1 \mathrm{~mL}$ dengan cara penyuntikan secara intraperitonial dengan konsentrasi bakteri 0 (kontrol), $10^{2}, 10^{4}, 10^{6}, 10^{8}, 10^{10} \mathrm{cfu} /$ $\mathrm{mL}$. Ikan yang telah diinfeksi kemudian dipelihara dalam akuarium berukuran $30 \mathrm{~cm} x$ $30 \mathrm{~cm} \times 50 \mathrm{~cm}$, volume air 20 liter. Selama pemeliharaan ikan diamati perkembangan, gejala klinis dan dihitung jumlah kematiannya setiap 12 jam. Selama pemeliharaan diberi aerasi dan kualitas air diamati. Data sintasan ikan dianalisis dengan metode Dragsted Behrens (Hubert, 1980 dalam Anonim, 2007).

$$
m=X_{1}+d \frac{50-\% X_{1}}{\% X_{1+1}-\% X_{1}}
$$

di mana:

$$
\begin{aligned}
\mathrm{m}_{\mathrm{X}}= & \log \mathrm{LC} C_{50} \\
\mathrm{X}_{1}= & \log \text { dosis di bawah } \mathrm{LC}_{50} \text { (Log of lower } \\
& L C_{50} \text { dosage) } \\
\mathrm{d}= & \text { Selisih log dosis di bawah } \mathrm{LC}_{50} \text { dan di } \\
& \text { atas } \mathrm{LC} C_{50} \text { (Log difference of lower } L C_{50} \\
& \text { and upper } L C_{50} \text { dosages) }
\end{aligned}
$$

$\% \mathrm{X}_{1}=$ Persentase kematian kumulatif pada dosis di bawah $\mathrm{LC}_{50}$ (Precentage of cummulative mortality of lower $L C_{50}$ dosage)

$\% \mathrm{X}_{1+1}=$ Persentase kematian kumulatif pada dosis di atas $\mathrm{LC}_{50}$ (Precentage of cummulative mortality of upper $L C_{50}$ dosage)

$\mathrm{LC}_{50}=$ Berada pada interval antilog (Located at the intervals of antilog)

\section{Uji Patogenitas}

Dari hasil uji $\mathrm{LC}_{50}$, diseleksi isolat bakteri yang memiliki patogenitas tinggi. Bakteri tersebut kemudian diuji patogenitasnya terhadap dua jenis ikan yang berbeda, yaitu ikan mas koki berukuran 5-7 cm dan ikan Celebes rainbow berukuran $4-6 \mathrm{~cm}$.

Wadah yang digunakan adalah akuarium berisi 20 liter air, dengan kepadatan 10 ekor per wadah.

Isolat murni E. tarda yang sudah diisolasi diinfeksikan ke ikan uji yaitu ikan mas koki dan ikan Celebes rainbow dari Sulawesi masingmasing 10 ekor dengan cara perendaman selama kurang lebih 1 minggu dengan konsentrasi bakteri 1,8 $810^{5} \mathrm{cfu} / \mathrm{mL}$ (untuk ikan mas koki) dan $2,3 \times 10^{7} \mathrm{cfu} / \mathrm{mL}$ (untuk ikan Celebes rainbow). Selama masa perendaman atau perlakuan diamati gejala klinis, perubahan makroskopis dan mikroskopis dari ikan uji.

\section{HASIL DAN BAHASAN}

\section{Isolasi dan Identifikasi}

Isolat E. tarda berasal dari luka pada tubuh, hati, dan ginjal sampel ikan mas dari Pontianak dan kura-kura Brazil dari Jakarta. Dan kemudian ditanamkan pada media Trypticase Soy Agar (TSA). Bakteri yang tumbuh kemudian dimurnikan dan diidentifikasi dengan melihat morfologi (sifat gram, oksidase, catalase, motilitas) dan sifat-sifat kultural lainnya seperti: kemampuan fermentasi, fisika, dan biokimia. Uji karakter biokimia dan fisika dilakukan pada semua isolat termasuk isolat ATCC secara konvensional.

Hasil identifikasi biokimia dan biofisika dari sampel ikan yang diisolasi menunjukkan Edwardsiella tarda yang mempunyai karakteristik: gram negatif, batang pendek, non acid fast, motil, produksi $\mathrm{H}_{2} \mathrm{~S}$, produksi gas pada fermentasi glukosa, sukrosa, laktosa positif (Tabel 1). Hal ini sesuai pendapat Plumb (1999), karakteristik utama dari E. tarda adalah pada motility, produksi indole dalam tryptone broth, 
Tabel 1. Hasil identifikasi karakteristik 2 isolat Edwardsiella tarda

Table 1. The results of characteristic identification of 2 isolates of Edwardsiella tarda

\begin{tabular}{lcc}
\hline \multicolumn{1}{c}{$\begin{array}{c}\text { Media } \\
\text { Medium }\end{array}$} & $\begin{array}{c}\text { Ikan mas Pontianak } \\
\text { Common carp Pontianak }\end{array}$ & $\begin{array}{c}\text { Kura-kura Brazilia } \\
\text { Brazillian turtles }\end{array}$ \\
\hline Gram test & - & - \\
Oxidase & + & + \\
Catalase & + & + \\
Motility & + & + \\
Indole & + & + \\
$\mathrm{H}_{2}$ S in TSIA & + & + \\
Voges-proskover & + & + \\
Urea hydrolysis & - & - \\
Lysine decarboxylase & + & + \\
Ornithine decarboxylase & - & - \\
Gelatine hydrolysis & + & + \\
Gas of glucose & + & + \\
Acid of Glucose & + & + \\
Lactose & + & + \\
Sucrose S & + & + \\
\hline
\end{tabular}

produksi $\mathrm{H}_{2} \mathrm{~S}$ pada agar miring TSI, produksi gas pada fermentasi glukosa, dapat mengubah nitrat menjadi nitrit, dan laktosa positif.

\section{Uji Lethal Concentration $50\left(\mathrm{LC}_{50}\right)$}

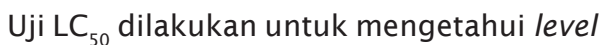
konsentrasi infeksi $E$. tarda terhadap ikan uji. Berdasarkan hasil uji LC $_{50}$ dan data sintasan ikan yang dihitung dengan metode DragstedBehrens, tingkat kepadatan isolat atipikal $E$. tarda terendah yang menyebabkan jumlah kematian ikan uji yang tinggi serta waktu kematian semakin singkat adalah konsentrasi yang akan digunakan untuk uji patogenitas. Isolat atipikal E. tarda merupakan bakteri patogen yang sangat berbahaya bagi hewan akuatik.

Hasil perhitungan LC $_{50}$ E. tarda terhadap ikan uji dari tingkat kematian, dan rata-rata waktu kematian. Isolat E. tarda yang diisolasi dari ikan nila Jogjakarta diinfeksikan ke ikan mas koki, isolat E. tarda dari kura-kura Brazil diinfeksikan ke ikan Celebes rainbow. Berdasarkan hasil tersebut terlihat bahwa konsentrasi yang dapat membunuh ikan Celebes rainbow: $2,3 \times 10^{7} \mathrm{cfu} / \mathrm{mL}$, ikan mas koki: $2,2 \times 10^{8} \mathrm{cfu} / \mathrm{mL}$, sehingga konsentrasi tersebut dipakai sebagai dosis infeksi pada uji patogenesitas E. tarda (Tabel 2, 3, 4, 5, 6). Hasil tersebut menunjukkan bahwa tingkat kematian ikan uji berkorelasi dengan semakin meningkatnya konsentrasi bakteri yang diinfeksikan.

\section{Gejala Klinis yang Timbul}

Gejala klinis ikan mas koki dan ikan Celebes rainbow yang diinfeksi dengan isolat E. tarda yang berbeda menunjukkan gejala klinis yang mirip pada hari keenam, yaitu menurunnya nafsu makan, reaksi terhadap rangsangan yang berkurang, cara berenang yang lamban, dan adanya lesi kemerahan pada ekor dan sirip (Tabel 7).

Gejala klinis yang terjadi pada ikan uji menunjukkan kemiripan dengan penelitian pada ikan Anabas testudineus yang diinfeksi dengan dosis dengan $\mathrm{LC}_{50}$ secara intraperitoneal akan menunjukkan gejala klinis anoreksia, berenang lamban di dasar, perut bengkak, kulit berwarna kuning hingga kemerahan, hemoragi dan hiperemi pada ventral tubuh dan dasar sirip, sisik menjadi kasar, serta insang pucat sebelum mati (Sahoo et al., 2000).

Perubahan makroskopik patologik anatomik menunjukkan adanya kebengkakan perut, tubuh, insang pucat, lesi pada pangkal 
Tabel 2. Persentase mortalitas Celebes rainbow pada konsentrasi E. tarda yang berbeda

Table 2. Mortality percentage of Celebes rainbow treated with different concentrations of E. tarda

\begin{tabular}{|c|c|c|c|c|c|c|c|c|c|}
\hline \multirow{2}{*}{$\begin{array}{c}\text { Konsent rasi } \\
\text { bakt eri } \\
\text { Concentration } \\
\text { of bacteria }\end{array}$} & \multirow{2}{*}{$\begin{array}{c}\text { Ulangan } \\
\text { Repitition }\end{array}$} & \multicolumn{6}{|c|}{$\begin{array}{l}\text { Waktu pengamatan (hari ke-) } \\
\text { Observation time (day) }\end{array}$} & \multirow{2}{*}{$\begin{array}{l}\text { Jumlah } \\
\text { (ekor) } \\
\text { Amount } \\
\text { (Ind.) }\end{array}$} & \multirow{2}{*}{$\begin{array}{l}\text { Persent ase } \\
\text { Percentage } \\
\text { (\%) }\end{array}$} \\
\hline & & I & II & III & IV & V & VI & & \\
\hline \multirow[t]{3}{*}{0} & 1 & 0 & 0 & 0 & 0 & 0 & 0 & 0 & 0 \\
\hline & 2 & 0 & 0 & 0 & 0 & 0 & 0 & 0 & 0 \\
\hline & 3 & 0 & 0 & 0 & 0 & 0 & 0 & 0 & 0 \\
\hline \multirow[t]{3}{*}{$10^{2}$} & 1 & 0 & 0 & 0 & 0 & 1 & 1 & 2 & 20 \\
\hline & 2 & 0 & 0 & 0 & 0 & 1 & 1 & 2 & 20 \\
\hline & 3 & 0 & 0 & 0 & 1 & 1 & 1 & 3 & 30 \\
\hline \multirow[t]{3}{*}{$10^{4}$} & 1 & 0 & 1 & 1 & 2 & 1 & 1 & 6 & 60 \\
\hline & 2 & 0 & 0 & 1 & 2 & 1 & 1 & 5 & 50 \\
\hline & 3 & 0 & 0 & 1 & 1 & 1 & 2 & 5 & 50 \\
\hline \multirow[t]{3}{*}{$10^{6}$} & 1 & 0 & 1 & 1 & 2 & 2 & 2 & 8 & 80 \\
\hline & 2 & 0 & 1 & 3 & 2 & 2 & 1 & 9 & 90 \\
\hline & 3 & 0 & 1 & 1 & 2 & 3 & 1 & 8 & 80 \\
\hline \multirow[t]{3}{*}{$10^{8}$} & 1 & 0 & 1 & 3 & 4 & 2 & 0 & 10 & 100 \\
\hline & 2 & 0 & 2 & 4 & 3 & 1 & 0 & 10 & 100 \\
\hline & 3 & 0 & 2 & 3 & 4 & 1 & 0 & 10 & 100 \\
\hline \multirow[t]{3}{*}{$10^{10}$} & 1 & 0 & 2 & 3 & 3 & 2 & 0 & 10 & 100 \\
\hline & 2 & 0 & 1 & 4 & 3 & 2 & 0 & 10 & 100 \\
\hline & 3 & 0 & 2 & 3 & 4 & 1 & 0 & 10 & 100 \\
\hline
\end{tabular}

Tabel 3. Perhitungan uji $\mathrm{LC}_{50}$ E. tarda terhadap Celebes rainbow Table 3. Calculation test of $L C_{50}$ E. tarda on Celebes rainbow

\begin{tabular}{ccccccccc}
\hline $\begin{array}{c}\text { Kons. } \\
\text { Cons. }\end{array}$ & $\begin{array}{c}\text { Log kons. } \\
\text { Log of cons. }\end{array}$ & $\mathbf{n}$ & $\mathbf{r}$ & $\mathbf{n}-\mathbf{r}$ & $\Sigma \mathbf{r}$ & $\Sigma(\mathbf{n}-\mathbf{r})$ & Total (T) & $\frac{\Sigma \mathbf{r} \times \mathbf{1 0 0 \%}}{\mathbf{T}}$ \\
\hline $10^{0}$ & 0 & 30 & 0 & 30 & 0 & 86 & 86 & 0 \\
$39 \times 10^{2}$ & 3.6 & 30 & 4 & 26 & 4 & 60 & 64 & 6.25 \\
$39 \times 10^{4}$ & 5.6 & 30 & 12 & 18 & 16 & 42 & 58 & 27.59 \\
$39 \times 10^{6}$ & 7.6 & 30 & 18 & 12 & 34 & 30 & 64 & 53.13 \\
$39 \times 10^{8}$ & 9.6 & 30 & 30 & 0 & 64 & 30 & 94 & 68.09 \\
$39 \times 10^{10}$ & 11.6 & 30 & 30 & 0 & 94 & 30 & 124 & 75.81 \\
\hline
\end{tabular}

Perhitungan uji LC $_{50}$ E. tarda terhadap Celebes rainbow sebagai berikut:

$$
\begin{aligned}
& \log \mathrm{LC}_{50}=\left[\frac{\frac{50-27,59}{5,6+2}}{53,13-27,59}\right] \\
& =5,6+1,76 \\
& =7,36 \\
& \mathrm{LC}_{50}=\text { Antilog 7,36 } \\
& =5,6+2 \times(0,88) \\
& =22908676 \\
& \mathrm{LC}_{50}=2,3 \times 10^{7} \mathrm{sel} / \mathrm{mL}
\end{aligned}
$$


Tabel 4. Persentase mortalitas ikan mas koki pada konsentrasi E. tarda yang berbeda

Table 4. Mortality percentage of goldfish treated with different concentration of E. tarda

\begin{tabular}{|c|c|c|c|c|c|c|c|c|c|}
\hline \multirow{2}{*}{$\begin{array}{c}\text { Konsent rasi } \\
\text { bakt eri } \\
\text { Concentration } \\
\text { of bacteria }\end{array}$} & \multirow{2}{*}{$\begin{array}{c}\text { Ulangan } \\
\text { Repitition }\end{array}$} & \multicolumn{6}{|c|}{$\begin{array}{l}\text { Wakt u pengamatan (hari ke-) } \\
\text { Observation time (day) }\end{array}$} & \multirow{2}{*}{$\begin{array}{c}\text { Jumlah } \\
\text { (ekor) } \\
\text { Amount } \\
\text { (Ind.) }\end{array}$} & \multirow{2}{*}{$\begin{array}{c}\text { Persentase } \\
\text { Percentage } \\
\text { (\%) }\end{array}$} \\
\hline & & I & II & III & IV & $\mathbf{v}$ & VI & & \\
\hline \multirow[t]{3}{*}{0} & 1 & 0 & 0 & 0 & 0 & 0 & 0 & 0 & 0 \\
\hline & 2 & 0 & 0 & 0 & 0 & 0 & 0 & 0 & 0 \\
\hline & 3 & 0 & 0 & 0 & 0 & 0 & 0 & 0 & 0 \\
\hline \multirow[t]{3}{*}{$10^{2}$} & 1 & 0 & 0 & 0 & 0 & 1 & 1 & 2 & 20 \\
\hline & 2 & 0 & 0 & 0 & 0 & 1 & 0 & 1 & 10 \\
\hline & 3 & 0 & 0 & 0 & 0 & 1 & 1 & 2 & 20 \\
\hline \multirow[t]{3}{*}{$10^{4}$} & 1 & 0 & 0 & 1 & 2 & 1 & 1 & 5 & 50 \\
\hline & 2 & 0 & 0 & 0 & 1 & 1 & 2 & 4 & 40 \\
\hline & 3 & 0 & 0 & 1 & 1 & 1 & 1 & 4 & 40 \\
\hline \multirow[t]{3}{*}{$10^{6}$} & 1 & 0 & 0 & 2 & 3 & 2 & 2 & 9 & 90 \\
\hline & 2 & 0 & 1 & 1 & 2 & 2 & 2 & 8 & 80 \\
\hline & 3 & 0 & 0 & 1 & 1 & 2 & 3 & 7 & 70 \\
\hline \multirow[t]{3}{*}{$10^{8}$} & 1 & 0 & 1 & 2 & 3 & 3 & 1 & 10 & 100 \\
\hline & 2 & 0 & 3 & 2 & 3 & 2 & 0 & 10 & 100 \\
\hline & 3 & 0 & 2 & 3 & 4 & 2 & 0 & 10 & 100 \\
\hline \multirow[t]{2}{*}{$10^{10}$} & 1 & 0 & 3 & 2 & 3 & 2 & 0 & 10 & 100 \\
\hline & 2 & 0 & 1 & 3 & 3 & 3 & 0 & 10 & 100 \\
\hline
\end{tabular}

Tabel 5. Perhitungan uji LC $_{50}$ E. Tarda terhadap ikan mas koki

Table 5. Test calculation of $L C_{50}$ E. tarda on goldfish

\begin{tabular}{ccccccccc}
\hline $\begin{array}{c}\text { Kons. } \\
\text { Cons. }\end{array}$ & $\begin{array}{c}\text { Log kons. } \\
\text { Log of cons. }\end{array}$ & $\mathbf{n}$ & $\mathbf{r}$ & $\mathbf{n}-\mathbf{r}$ & $\Sigma \mathbf{r}$ & $\Sigma(\mathbf{n}-\mathbf{r})$ & Total (T) & $\frac{\Sigma \mathbf{r} \times 100 \%}{\mathbf{T}}$ \\
\hline $10^{0}$ & 0 & 30 & 0 & 30 & 0 & 99 & 99 & 0 \\
$39 \times 10^{2}$ & 3.6 & 30 & 2 & 28 & 1 & 71 & 73 & 2.74 \\
$39 \times 10^{4}$ & 5.6 & 30 & 8 & 22 & 6 & 49 & 59 & 16.95 \\
$39 \times 10^{6}$ & 7.6 & 30 & 14 & 16 & 15 & 33 & 57 & 42.11 \\
$39 \times 10^{8}$ & 9.6 & 30 & 27 & 3 & 29 & 30 & 81 & 62.96 \\
$39 \times 10^{10}$ & 11.6 & 30 & 30 & 0 & 54 & 30 & 111 & 72.97 \\
\hline
\end{tabular}

Perhitungan uji $\mathrm{LC}_{50}$ E. Tarda terhadap ikan mas koki sebagai berikut:

$$
\begin{aligned}
\log \mathrm{LC}_{50} & =\left[\frac{50-42,11}{\frac{7,6+2}{62,96-42,11}}\right] \quad \begin{array}{ll}
\mathrm{LC}_{50} & =\text { Antilog } 8,36 \\
& =229086765 \\
& =2,2 \times 10^{8} \mathrm{sel} / \mathrm{mL}
\end{array} \\
& =7,6+2 \times(0,38) \\
& =7,6+0,76 \\
& =8,36
\end{aligned}
$$


Tabel 6. Hasil uji Lethal Concentration $50\left(\mathrm{LC}_{50}\right)$ E. tarda yang diinfeksikan pada ikan mas koki dan ikan Celebes rainbow

Table 6. Result of Lethal Concentration $50\left(L C_{50}\right)$ E. tarda infected to goldfish and Celebes rainbow

\begin{tabular}{lllcc}
\hline $\begin{array}{c}\text { Asal isolat } \\
\text { Origin of Isolate }\end{array}$ & $\begin{array}{c}\text { Asal ikan } \\
\text { Origin of fish }\end{array}$ & $\begin{array}{c}\text { Ikan infeksi } \\
\text { Infected fish }\end{array}$ & $\begin{array}{c}\mathrm{LC}_{50} \\
(\mathbf{s e l} / \mathbf{m L})\end{array}$ & $\begin{array}{c}\text { Lama (hari) } \\
\text { Period (days) }\end{array}$ \\
\hline Nila (O. niloticus) & Jogjakarta & Mas Koki & $2.2 \times 10^{8}$ & 6 \\
Kura-kura (Turtles) & Brazil & C. rainbow & $2.3 \times 10^{7}$ & 6 \\
\hline
\end{tabular}

Tabel 7. Gejala klinis ikan yang diinfeksi berbagai isolat E. tarda

Table 7. Clinical symptoms of fish which infected by E. tarda

\begin{tabular}{lcc}
\hline \multicolumn{1}{c}{$\begin{array}{c}\text { Gejala klinis } \\
\text { Clinical symptoms }\end{array}$} & $\begin{array}{c}\text { Mas koki } \\
\text { Goldfish }\end{array}$ & C. rainbow \\
\hline $\begin{array}{l}\text { Anoreksi } \\
\text { Le si kulit \& pangkal sirip }\end{array}$ & + & + \\
$\begin{array}{l}\text { Lession of scale \& fin } \\
\text { Rangsangan terhadap cahaya }\end{array}$ & + & + \\
$\begin{array}{l}\text { Stimulus to the light } \\
\text { Cara berenang }\end{array}$ & + & + \\
Swimming style & + & + \\
\hline
\end{tabular}

sirip, ginjal, dan hati bengkak pada ikan mas koki dan ikan Celebes rainbow (Gambar 1 dan 2; Tabel 8).

Hal ini sesuai pendapat Meyer \& Bullock (1973) bahwa E. tarda yang diinfeksikan pada Channel Catfish menunjukkan gejala luka-luka kecil yang berdiameter $3-5 \mathrm{~cm}$. Luka tersebut terletak pada Postero-lateral. Pada permukaan kulit, luka terlihat seperti kekurangan pigmen, cembung, bengkak. (Austin \& Austin, 1987). Kubota et al. (1981) meneliti dengan menggunakan ikan Tilapia, menunjukkan gejala antara lain: kehilangan pigmen, luka pada abdomen, perdarahan pada anus, dan mata keruh.

Pada penelitian ini ikan uji menunjukkan adanya gejala klinis pada hari kedua. Ikan yang diinfeksi mengalami penurunan nafsu makan, pergerakan lambat/berenang tidak aktif, dan kehilangan keseimbangan. Dari hasil isolasi dan identifikasi $E$. tarda pada target organ insang, hati, dan ginjal, didapatkan hasil positif E. tarda yang diinfeksikan pada ikan uji. Hal ini menunjukkan bahwa E. tarda dengan konsentrasi tersebut bersifat patogen terhadap ikan uji.
Sistem metabolisme ikan terpengaruh, terjadi hyperaemia dan septicemia dengan membesarnya ginjal ikan. Pada infeksi yang berat berkembang menjadi hyperaemia yang parah akibat penyumbatan darah pada semua sirip ikan, berlanjut dengan echymotik atau petechial haemorrhage di berbagai permukaan tubuh. Anus membengkak dan hiperaemik. Peritoneum hiperemik, oedem, melajutkan terjadi abses. Patogenitas E. tarda yang terdapat pada satu spesies ikan dengan spesies yang lain berbeda, begitu pula untuk daerah sebaran yang satu dengan daerah sebaran yang lainnya berbeda (Inglis et al., 1993).

\section{KESIMPULAN}

1. Dari penelitian ditemukan adanya persamaan gejala klinis yang terjadi pada ikan mas koki dan Celebes rainbow yang diinfeksi dengan isolat $E$. tarda yang berbeda, yaitu terjadinya kebengkakan perut dan tubuh, insang pucat, lesi pada pangkal sirip, dan bengkak ginjal dan hati. 

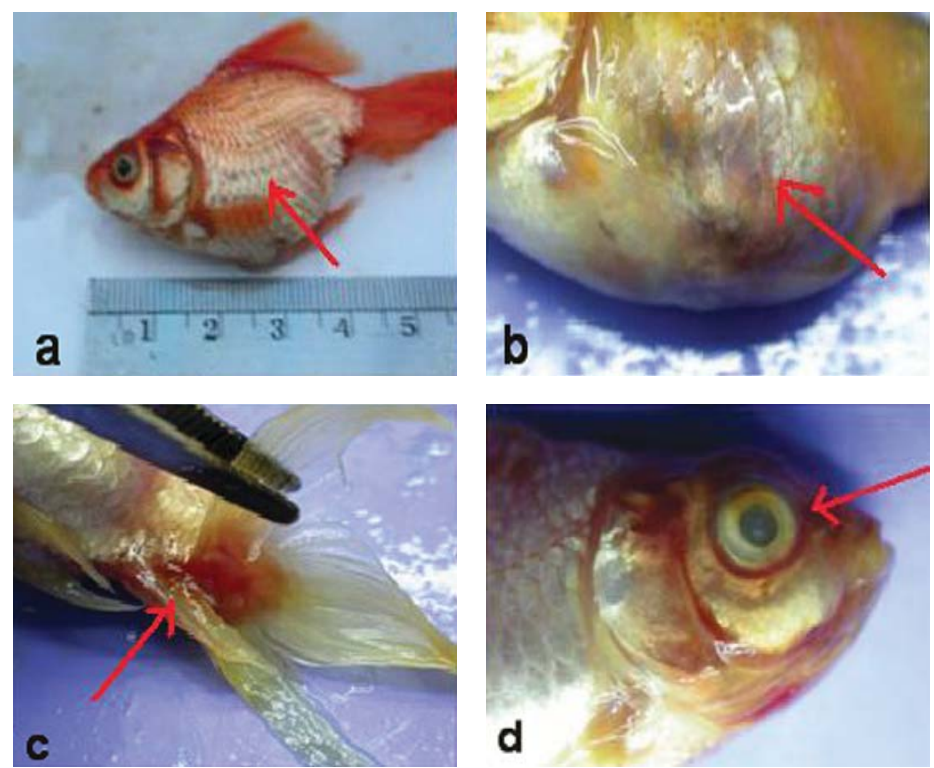

Keterangan: a dan b. perut bengkak; c. pangkal ekor haemoraghic; d. mata buram Note: a \& b. abdominal swelling; c. haemoraghic tale; $d$. blurry eyes

Gambar 1. Kondisi ikan mas koki (C. auratus) setelah diinfeksi dengan E. tarda Figure 1. Goldfin (C. auratus) after infected by E. tarda
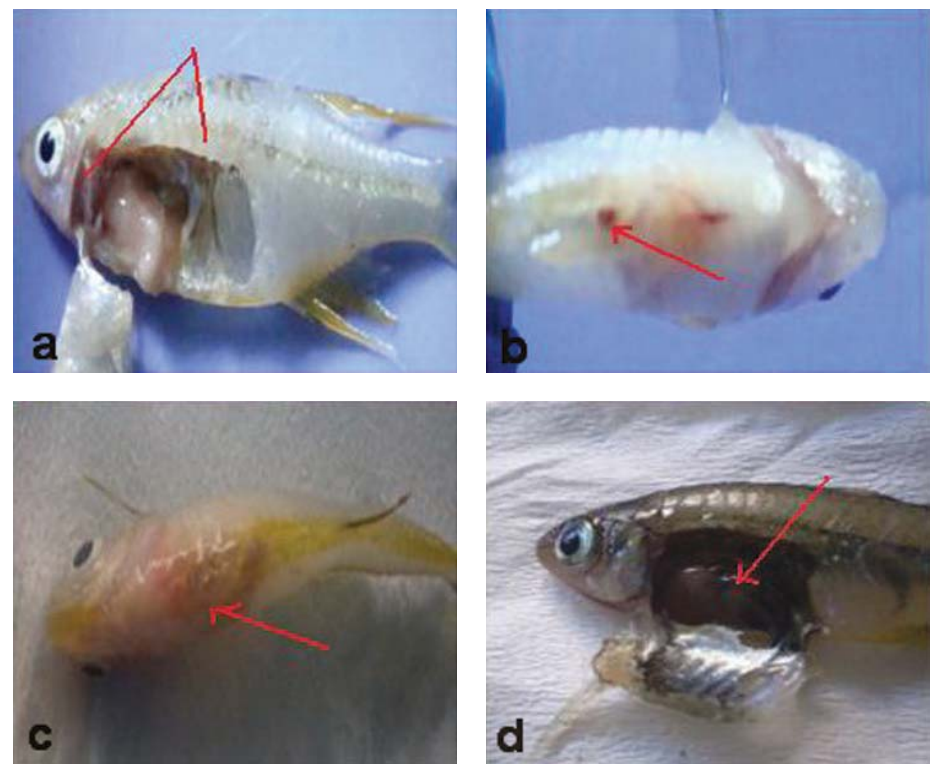

Keterangan: a. tubuh dan insang pucat, insang rusak; b. anus bengkak dan merah; c. perut bengkak dan merah; d. ginjal dan hati bengkak, serta usus berwarna hitam Note: $a$. body and gills were pale, damage gills; $b$. swelling and redden anal organ; c. swelling and redden abdominal; $d$. swelling kidney and liver, intestine was black

Gambar 2. Ikan Celebes rainbow setelah diinfeksi E. tarda

Figure 2. Celebes rainbow infected by E. tarda 
Tabel 8. Perubahan makroskopis setelah infeksi E. tarda

Table 8. Macroscopic changes on fish after E. tarda infection

\begin{tabular}{|c|c|c|}
\hline Organ & C. rainbow & $\begin{array}{c}\text { Koki } \\
\text { Goldfish }\end{array}$ \\
\hline Kulit (Scale) & - & Lesi (Lession), sisik rontok (fallen out scale) \\
\hline Sirip (Fin) & - & Merah, geripis (Redden) \\
\hline Abdomen & Bengkak (Swollen) & Hemoragi (Haemoraghic), bengkak (swollen) \\
\hline Insang (Gill) & Puc at (Pale) & Pucat (Pale) \\
\hline Hati (Liver) & Bengkak (Swollen) & Bengkak (Swollen) \\
\hline Ginjal (Kidney) & Bengkak (Swollen) & Bengkak (Swollen) \\
\hline Operkulum & - & Merah (Redden) \\
\hline Usus (Intestine) & Rusak (Damaged) & Bengkak (Swollen) \\
\hline
\end{tabular}

2. Nilai $\mathrm{LC}_{50}$ E. tarda untuk ikan mas koki adalah $2,2 \times 10^{8} \mathrm{cfu} / \mathrm{mL}$ dan untuk ikan Celebes rainbow adalah $2,3 \times 10^{7} \mathrm{cfu} / \mathrm{mL}$.

3. Patogenesitas akibat infeksi E. tarda terjadi pada hari ke-4 dan kerusakan organ pada terjadi pada hari ke-7 setelah infeksi.

4. E. tarda merupakan patogen pada ikan mas koki dan ikan Celebes rainbow.

\section{DAFTAR ACUAN}

Ainsworth, A.J., Capley, G., Waterstreet, P., \& Munson, D. 1986. Use of Monoclonal Antibodies In The Indirect Fluorescent Antibody Technique (IFA) For The Diagnosis of Edwardsiella ictaluri. Journal of Fish Diseases, 9: 439-444.

Amandi, A., Hiu, S.F., Ronovec, J.S., \& Fryer, J.L. 1982. Isolation and Characterizations of Edwardsiella tarda From Fall Chinook Salmon (Oncorhynchus tsawytscha). Applied and Environmental Microbiology, 43: 1380-1384.

Anonim. 1993. Diskripsi Hama dan Penyakit Ikan Karantina Golongan Bakteri. Pusat Karantina Pertanian. Jakarta, hlm. 7-12.

Anonim. 2007. Petunjuk Praktikum Penyakit Ikan Bakterial. Laboratorium Hama dan Penyakit Ikan Jurusan Perikanan, Fakultas Pertanian Universitas Gajah Mada. Yogyakarta.

Austin, B. \& Austin, D.A. 1987. Bacterial Fish Pathogen: Disease In Farmed And Wild Fish. Ellis, Horwood Ltd., Chichaster. John Wiley \& Sons. New York, p. 109-195.

Blazer, V.S. 1991. Piscine macrophage function and nutritional influences: a review. J. Aquat. Anim. Health, 3: 77-86.
Coles, B.M., Stroud, R.K., \& Sheggeby, S. 1978. Isolation of Edwardsiella tarda From Three Oregon Sea Mammals. Journal Of Wild Diseases.

Frerichs, G.N. \& Millar, S.D. 1993. Manual for the Isolation and Identification of Fish Bacterial Pathogens. Institute of Aquaculture, University of Stirling, Scotland.

Hirono, I., Tange, N., \& Aoki, T. 1997. Iron-regulated haemolysin gene from Edwardsiella tarda. Molekuler Microbiology, 24: 851856.

Inglis, V., Robert, R.J., \& Bromage, N.R. 1993. Bacterial Disease of Fish. Blackweell Scientific Publication. Oxford, p. 61-75.

Janda, J. \& Abbott, S. 1993. Expession of an iron-regulated hemolysin by Edwardsiella tarda in human disease. Clinical Infection Disease, 48: 742-748.

Janda, J.M., Abbott., S.L., Kroske-Bystrom, S., Cheung, W.K.W., Powers, C., Kokka, R.P., \& Tamura, K. 1991. Pathogenic Properties of Edwardsiella species. J. Clin. Microbial., 29: 1997-2001.

Kubota, S.S., Kaige, N., Miyazaki, T., \& Miyashita, T. 1981. Histopathological studies on edwardsiellosis of tilapia. I. Natural infection. Bull. Fac. Fish Mie. Univ., 9: 155-165.

Lee, S.W., Najlah, M., \& Lee, K.L. 2006. Phenotypic Characterization and Numerical Analysis of Edwardsiella tarda In Wild Asia Swap Eels, Monopterus albus in Terengganu. Journal of Sustainability Science ang Management, 1: 85-91.

Ling, S.H.M., Wang, X.H., Xie, L., Lim, T.M., \& Leung, K.Y. 2000. Use of Green Fluorescent Protein (GFP) to Study The Invasion 
Pathways of Edwarsiella tarda In Invivo and In Vitne Fish Models. Journal of Microbiology, 146: 7-19.

Meyer, F.P. \& Bullock, G.L. 1973. Edwardsiella tarda, a new pathogen of channel catfish (Ictalurus punctatus). Appl. Microbiology, 25: 155-156.

Plumb, J.A. 1999. Health Maintenance and Principal Microbial Diseases of Cultured Fishes. Iowa State University, Ames.

Post, G. 1987. Texbook of Fish Health. T.F.H. Publications Inc., hlm. :31-37.

Rao, Putanae, S. Srinivasa, Lim, Tit Meng, \& Leung, Ka Yin. 2001. Oposonized Virulent Edwardsiella tarda Strains Are Able To Adhere to and Survive and Replicate Within Fish Phagocytes but Fail To Stimulate Reactive Oxygen Intermediates. American Society For Microbiology. USA.
Rao, Putanae, S. Srinivasa, Lim, Tit Meng, \& Leung, Ka Yin. 2002. Functional Genomics Approach to The Identification of Virulence Genes Involved In Edwardsiella tarda Pathogenesis. American Society For Microbiolog, 34: 235-241.

Sahoo, P.K., Swain, P., Sahoo, S.K., Mukherjee, \& Sahu, A.K. 2000. Pathology Caused by the Bacterium Edwarsiella tarda in Anabas testudineus (Bloch). J. Asian Fisheries, 13: 357-362.

Thune, R.L., Stanley, L.A., \& Couper, R.K. 1993. Pathogenesis of Gram-negative Bacterial Infection In Warm Water Fish. Annu. Rev. Fish. Dis., 3: 37-68.

Zhang, X.H. \& Austin, B. 2000. Pathogenicity of Vibrio Harveyi to Salmonids. Journal of Fish Diseases, 23: 93-102. 